\title{
Potential Impact of Spacing and Fertilizer Levels on the Flowering, Productivity and Economic Viability of Hybrid Bhendi (Abelmoschus esculentus L. Moench) under Drip Fertigation System
}

\author{
Govindarasu Rajaraman ${ }^{1}$, Lakshmanan Pugalendhi ${ }^{2}$ \\ ${ }^{1}$ Department of Vegetable Crops, Horticultural College and Research Institute, Tamil Nadu Agricultural University, Coimbatore, \\ India; ${ }^{2}$ Tapioca and Castor Research Station, Tamil Nadu Agricultural University, Yethapur, Tamil Nadu, India. \\ Email: hortraja@gmail.com
}

Received July $1^{\text {st }}, 2013$; revised August $1^{\text {st }}, 2013$; accepted August $20^{\text {th }}, 2013$

Copyright (C 2013 Govindarasu Rajaraman, Lakshmanan Pugalendhi. This is an open access article distributed under the Creative Commons Attribution License, which permits unrestricted use, distribution, and reproduction in any medium, provided the original work is properly cited.

\begin{abstract}
Drip irrigation provides an efficient method of fertilizer delivery and allows precise timing and uniform distribution of applied nutrients. Fertilizer application through drip irrigation (fertigation) can reduce fertilizer usage and minimize groundwater pollution due to fertilizer leaching from excessive irrigation. For this purpose, field experiments were carried out in the farmers' field at Thoppur, Dharmapuri District, Tamil Nadu, during 2010-2012 to study the effect of spacing and fertilizer levels on the flowering, pod yield and economic viability of Bhendi Hybrid (Abelmoschus esculentus L. Moench) under drip fertigation system. The treatments consisted of two spacings $\left(\mathrm{M}_{1}-60 \times 45 \mathrm{~cm}\right.$ and $\mathrm{M}_{2}-$ $60 \times 30 \mathrm{~cm}$ ) and eight drip fertigation levels ( $\mathrm{S}_{1}$-Drip fertigation with WSF at 125 per cent RDF + Azophosmet + Humic acid, $\mathrm{S}_{2}$-Drip fertigation with WSF at 100 per cent RDF + Azophosmet + Humic acid, $\mathrm{S}_{3}$-Drip fertigation with WSF at 75 per cent RDF + Azophosmet + Humic acid, $\mathrm{S}_{4}$-Drip fertigation with WSF at 100 per cent RDF, $\mathrm{S}_{5}$-Drip fertigation with SF at 125 per cent RDF + Azophosmet + Humic acid, $\mathrm{S}_{6}$-Drip fertigation with SF at 100 per cent RDF + Azophosmet + Humic acid, $\mathrm{S}_{7}$-Drip fertigation with SF at 75 per cent RDF + Azophosmet + Humic acid, $\mathrm{S}_{8}$-Drip fertigation with SF at 100 per cent RDF), and were replicated thrice in a split plot design. Results showed that the earliest flowering (26.21 days), 50\% flowering (51.31), number of flowers per plant (25.33) and highest pod yield of $596.70 \mathrm{~g} /$ plant, $24.91 \mathrm{t} / \mathrm{ha}$ was registered in drip fertigation at 100 per cent recommended dose of fertilizers as water soluble fertilizer combination with Azophosmet and humic acid under wider spacing. The economics of the study clearly showed that drip fertigation at 100 per cent recommended dose of fertilizers as water soluble fertilizer along with Azophosmet and humic acid under wider spacing was found to record higher BCR of 2.99.
\end{abstract}

Keywords: Flowering; Pod Yield; Economics; Fertilizers; Spacing; Bhendi Hybrid

\section{Introduction}

Bhendi (Abelmoschus esculentus L. Moench) is an important vegetable crop widely grown in the world. It is belonging to the family Malvaceae and native to Africa and the crop comes up well in tropical and sub tropical lowland regions of Asia, America and warmer parts of Mediterranean region. In Bhendi, it is most desirable and also essential to achieve the twin objective of maximum yield and the best quality simultaneously, and this could be achieved largely by providing the optimum plant population per unit area and balanced nutrition under field conditions, which could be provided by optimizing the spacing and fertilizer levels. Obviously, these two factors will not only enhance the productivity, but also decide the ultimate commercial success of vegetable crops. It is essential to provide optimum plant population density per unit area by adjusting the spacing levels in bhendi crop, unlike in normal spacing the plants grown in closer spacing exhibited more vertical growth but gave less yield and poor quality for need of sufficient space, light, nutrient and moisture due to heavier plant population pressure [1]. Whereas, the plants grown in the wider 
spacing exhibit more horizontal and continuous vegetative growth due to less population pressure per unit area but they also give less yield per unit area [2]. However the plants grown under normal spacing will have optimum population density per unit area, which provides optimum conditions for luxuriant crop growth and better plant canopy area due to maximum light interception, photosynthetic activity, assimilation and accumulation of more photosynthates into plant system, and hence they produce more yields with best quality traits [3]. Bhendi responds well to the application of fertilizers and is reported to be a heavy feeder of NPK. Efficient use of fertilizer and water is highly critical to sustained agricultural production. Drip irrigation is often preferred over other irrigation methods because of the former's high water-application efficiency on account of reduced losses, surface evaporation and deep percolation. Because of high frequency water application, concentrations of salts remain manageable in the rooting zone [4]. Fertilizers applied under traditional methods are generally not utilized efficiently by the crop. In fertigation, nutrients are applied through emitters directly into the zone of maximum root activity, and consequently fertilizer-use efficiency can be improved over conventional method of fertilizer application. Generally crop response to fertilizer application through drip irrigation has been excellent, and frequent nutrient applications have improved the fertilizeruse efficiency [5]. Bar Yosef and Sagiv [6] reported fertilizer saving and increase in bhendi yield due to fertigation. For that purpose, a better understanding of the impact of current practices on the crop and on losses of water and nutrients from the root zone is necessary, which should be obtained from a sound base of field experimentation and environmental mechanics. Fertigation through drip system is an innovative technology for maximizing the yield. Though the cost of drip irrigation unit was high, considering longer life period of drip irrigation system, the benefit accrued out of drip irrigation will last for longer period. Fertigation involved an additional cost using water soluble fertilizers. However, the additional cost towards WSF was largely compensated by higher net return obtained by higher yield and quality produces. High net return of bhendi could be assured by increasing the productivity by adopting judicious management practices.

Keeping in this view, the present investigation was under taken to assess the effect of of spacing and fertilizer levels on the flowering, productivity and economics of Bhendi Hybrid (COBhH1) under drip fertigation system.

\section{Materials and Methods}

A field trial was conducted to study the effect of spacing and fertilizer levels on the flowering, productivity and economic viability of Bhendi Hybrid (Abelmoschus esculentus L. Moench) under drip fertigation system at Thoppur village in Dharmapuri district of Tamil Nadu, India during 2010-2012 during two Rabi and one Summer seasons. The experiment was laid out in split plot design (SPD) with three replications. Recommended dose of fertilizers (NPK@200:100:100 kg/ha), using liquid bio inoculant (Azophosmet @ 0.5 per cent) @ 750 ml/ha, Liquid bio stimulant (Humic acid @ 0.4 per cent) @ 2.5 litre/ha at 15 and 30 DAS through drip irrigation. WSF 100 per cent NPK applied through drip fertigation system and SF 100 per cent $P$ applied as basal and 100 per cent $\mathrm{N}$ and $\mathrm{K}$ applied through drip fertigation. The water soluble fertilizer sources for supplying NPK through drip irrigation were urea, poly feed, MAP and Multi-K. The straight fertilizer sources for supplying NK through drip irrigation were urea and MOP and the 100 per cent $\mathrm{P}$ applied as SSP as basal. Bhendi hybrid (COBhH1) was used for the study. The treatments consisted of two levels of spacing in main plots and eight levels of drip fertigation in sub plots. The treatments consisted spacing of $\mathrm{M}_{1}$ $(60 \times 45 \mathrm{~cm})$ and $\mathrm{M}_{2}(60 \times 30 \mathrm{~cm})$, drip fertigation levels of $\mathrm{S}_{1}$-Drip fertigation with WSF at 125 per cent RDF + Azophosmet + Humic acid, $S_{2}$-Drip fertigation with WSF at 100 per cent RDF + Azophosmet + Humic acid, $\mathrm{S}_{3}$-Drip fertigation with WSF at 75 per cent RDF + Azophosmet + Humic acid, $S_{4}$-Drip fertigation with WSF at 100 per cent RDF, $\mathrm{S}_{5}$-Drip fertigation with SF at 125 per cent RDF + Azophosmet + Humic acid, $\mathrm{S}_{6}-$ Drip fertigation with SF at 100 per cent RDF + Azophosmet + Humic acid, $\mathrm{S}_{7}$-Drip fertigation with SF at 75 per cent RDF + Azophosmet + Humic acid, $S_{8}$-Drip fertigation with SF at 100 per cent RDF.The number of days taken from sowing to the opening of first flower in each treatment and replication was re- corded as the days taken for first flowering and expressed in days. Total plants in the net plot were taken into ac- count for calculating days to 50 per cent flowering. The total number of days taken for blooming in about 50 per cent of the population in the net plot is recorded as days to 50 per cent flowering. The number of flowers per plant was counted individually from the tagged plants in each treatment and replication. For this ten plants from each treatment were tagged and the flowers that are bloomed were counted periodically and were expressed in number.

The crop yield was computed per hectare and the total income was worked out and expressed in Rs/ha based on the minimum market rate which was prevalent during the time of this experimentation. Net return was obtained by subtracting the cost of cultivation from gross return for each treatment and expressed in Rs/ha. The benefit cost 
ratio (BCR) was worked out by using the formula suggested by Palaniappan [7].

$$
\mathrm{BCR}=\frac{\text { Gross return }(\mathrm{Rs} / \mathrm{ha})}{\text { Total cost of cultivation }(\mathrm{Rs} / \mathrm{ha})}
$$

\section{Results and Discussion}

\subsection{Flowering Characters}

The flowering characters like days taken for first flower emergence, number of days to 50 per cent flowering and number of flowers per plant were significantly influenced by different levels of drip fertigation along with Azophosmet and humic acid (Table 1).

Under closer spacing there was delayed flowering. Wider spacing $\left(\mathrm{M}_{1}\right)$ registered early flowering (31.54 days), whereas in closer spacing $\left(\mathrm{M}_{2}\right)$, the flowering was noticed in 34.48 days. Application of 100 per cent recommended dose of fertilizers as water soluble fertilizer with Azophosmet and humic acid $\left(\mathrm{S}_{2}\right)$ showed early flowering with 26.57 days. In the interactions, application of 100 per cent recommended dose of fertilizers as water soluble fertilizer with Azophosmet and humic acid $\left(\mathrm{M}_{1} \mathrm{~S}_{2}\right)$ in wider spacing recorded early flowering (26.21 days). Takahashi et al. [8] also found that optimum dose of $\mathrm{N}, \mathrm{P}$ and $\mathrm{K}$ rates developed flower buds sooner than low levels of nutrients. The plants spaced at $60 \times 45 \mathrm{~cm}$ recorded minimum days to flowering than closer spacing of plants at $60 \times 30 \mathrm{~cm}$. Possible reason for delayed flowering at closer spacing might be high competition among the plants for nutrients, moisture and light [9]. The nutrients movement from source to sink would have taken place in a consistent manner and made the nutrient available to all plant parts for quick development of flower emergence. The result obtained in this study is in accordance with the findings of Ramalingam [10].

Among the interactions, application of 100 per cent recommended dose of fertilizers as water soluble fertilizer with Azophosmet and humic acid $\left(\mathrm{M}_{1} \mathrm{~S}_{2}\right)$ in wider spacing recorded less number of days for 50 per cent flowering with 51.31. This might be due to availability optimum level of nutrients in the root zone throughout the crop growth period. This was in line with the findings of Takahashi et al. [8]. The presence of $\mathrm{K}$ in humic acid might also be responsible for earliness to attain 50 per cent flowering [11].

In the main plot treatments, $\mathrm{M}_{1}$ (wider spacing) recorded more number of flowers per plant with 22.13 when compared to $\mathrm{M}_{2}$ (closer spacing) with 17.90. Different levels of drip fertigation showed significant differences among the treatments, $S_{2}$ (100 per cent recommended dose of fertilizers as water soluble fertilizer with

Table 1. Effect of spacing and drip fertigation on flowering characteristics and productivity of hybrid bhendi.

\begin{tabular}{|c|c|c|c|c|c|c|c|c|c|c|c|c|c|c|c|}
\hline \multirow{3}{*}{ Treatments } & \multicolumn{9}{|c|}{ Flowering characteristics } & \multicolumn{6}{|c|}{ Yield (or) Productivity } \\
\hline & \multicolumn{3}{|c|}{$\begin{array}{l}\text { Days taken to } \\
\text { first flowering }\end{array}$} & \multicolumn{3}{|c|}{$\begin{array}{l}\text { Number of days to } 50 \\
\text { per cent flowering }\end{array}$} & \multicolumn{3}{|c|}{$\begin{array}{c}\text { Number of flowers } \\
\text { per plant }\end{array}$} & \multicolumn{3}{|c|}{$\begin{array}{l}\text { Pod Yield } \\
\text { (g/plant) }\end{array}$} & \multicolumn{3}{|c|}{$\begin{array}{l}\text { Pod Yield } \\
\text { (t/ha) }\end{array}$} \\
\hline & $\mathbf{M}_{1}$ & $\mathbf{M}_{2}$ & Mean & $\mathbf{M}_{1}$ & $\mathbf{M}_{1}$ & $\mathbf{M}_{1}$ & $\mathbf{M}_{1}$ & $\mathbf{M}_{2}$ & Mean & $\mathbf{M}_{1}$ & $\mathbf{M}_{2}$ & Mean & $\mathbf{M}_{1}$ & $\mathbf{M}_{2}$ & Mean \\
\hline $\mathrm{S}_{1}$ & 26.73 & 29.84 & 28.29 & 55.87 & 59.32 & 57.60 & 24.71 & 18.86 & 21.79 & 596.70 & 382.60 & 489.65 & 22.10 & 21.25 & 21.68 \\
\hline $\mathbf{S}_{3}$ & 32.44 & 35.60 & 34.02 & 63.04 & 65.15 & 64.10 & 21.54 & 17.27 & 19.41 & 484.65 & 313.96 & 399.30 & 17.95 & 17.44 & 17.70 \\
\hline $\mathrm{S}_{4}$ & 30.49 & 35.21 & 32.85 & 60.12 & 63.07 & 61.60 & 22.26 & 18.48 & 20.37 & 534.21 & 337.95 & 436.07 & 19.79 & 18.78 & 19.28 \\
\hline $\mathbf{S}_{5}$ & 28.77 & 32.26 & 30.52 & 57.77 & 60.77 & 59.27 & 23.14 & 18.75 & 20.94 & 572.00 & 366.67 & 469.34 & 21.18 & 20.37 & 20.78 \\
\hline $\mathrm{S}_{6}$ & 34.18 & 36.91 & 35.54 & 66.35 & 68.64 & 67.49 & 21.35 & 17.16 & 19.26 & 439.96 & 284.54 & 362.25 & 16.30 & 15.81 & 16.05 \\
\hline $\mathrm{S}_{8}$ & 35.53 & 39.19 & 37.36 & 68.00 & 69.63 & 68.81 & 20.10 & 16.50 & 18.30 & 371.83 & 238.57 & 305.20 & 13.77 & 13.25 & 13.51 \\
\hline \multirow[t]{2}{*}{ Mean } & 31.54 & 34.48 & 33.01 & 61.40 & 64.61 & 63.01 & 22.13 & 17.90 & 20.01 & 497.35 & 318.00 & 407.67 & 19.09 & 18.30 & 18.04 \\
\hline & SEd & \multicolumn{2}{|c|}{ CD $(0.05 \%)$} & SEd & \multicolumn{2}{|c|}{ CD $(0.05 \%)$} & SEd & \multicolumn{2}{|c|}{ CD $(0.05 \%)$} & SEd & \multicolumn{2}{|c|}{ CD $(0.05 \%)$} & SEd & \multicolumn{2}{|c|}{ CD $(0.05 \%)$} \\
\hline $\mathbf{M}$ & 0.26983 & \multicolumn{2}{|c|}{1.16103} & 0.16988 & \multicolumn{2}{|c|}{0.73096} & 0.19313 & \multicolumn{2}{|c|}{0.83101} & 5.27857 & \multicolumn{2}{|c|}{22.71228} & 0.13876 & \multicolumn{2}{|c|}{0.59706} \\
\hline $\mathbf{S}$ & 0.44869 & \multicolumn{2}{|c|}{0.91912} & 0.78778 & \multicolumn{2}{|c|}{1.61373} & 0.33494 & \multicolumn{2}{|c|}{0.68612} & 8.32370 & \multicolumn{2}{|c|}{17.05078} & 0.29035 & \multicolumn{2}{|c|}{0.59476} \\
\hline MX S & 0.65201 & \multicolumn{2}{|c|}{1.58736} & 1.05589 & \multicolumn{2}{|c|}{2.22456} & 0.48335 & \multicolumn{2}{|c|}{1.16409} & 12.21107 & \multicolumn{2}{|c|}{30.15772} & 0.40839 & \multicolumn{2}{|c|}{0.94285} \\
\hline $\mathbf{S} \mathbf{X} \mathbf{M}$ & 0.63454 & \multicolumn{2}{|c|}{1.29983} & 1.11408 & \multicolumn{2}{|c|}{2.28216} & 0.47368 & \multicolumn{2}{|c|}{0.97032} & 11.77149 & \multicolumn{2}{|c|}{24.11345} & 0.41061 & 0.84 & 4112 \\
\hline
\end{tabular}


Azophosmet and humic acid) registered the maximum number of flowers per plant (22.96). Better uptake of potassium by the plants in the fertigation treatment would have helped in the transport of cytokinin and metabolites towards the sink. These results are in accordance with the findings of Salvadore et al. [12] in tomato. Similar trend of results have been documented by Prabhakar et al. [13], Meenakshi and Vadivel [14] and Kavitha [15]. This might be due to activity of humic acid consisting of active phenolic group that might have inhibited oxidase activity and promoted the prolonged persistence of IAA in plants which might have contributed to the increased number of flowers. Inhibition of peroxidase activity by humic acid due to auxin breakdown promoting the number of flowers was reported by Muscolo et al. [16] and Balumahendran [17].

\subsection{Pod Yield}

Among the spacings, the maximum pod yield per plant was noticed (Table 1) under the wider spacing $\mathrm{M}_{1}$ (497.35 g) whereas in closer spacing $\left(\mathrm{M}_{2}\right)$ it was 318.00 g. The 100 per cent recommended dose of fertilizers as water soluble fertilizer along with Azophosmet and humic acid $\left(\mathrm{S}_{2}\right)$ showed the maximum pod yield per plant with $538.42 \mathrm{~g}$, whereas in 75 per cent recommended dose of fertilizers as straight fertilizer with Azophosmet and humic acid $\left(\mathrm{S}_{7}\right)$ the pod yield per plant was $261.14 \mathrm{~g}$. Among the spacings, the maximum pod yield per hectare was noticed under the wider spacing $\mathrm{M}_{1}$ (19.09 $\mathrm{t} / \mathrm{ha}$ ), whereas in closer spacing $\left(\mathrm{M}_{2}\right)$ it was $18.30 \mathrm{t} / \mathrm{ha}$. Different levels of drip fertigation showed significant differences. The 100 per cent recommended dose of fertilizers as water soluble fertilizer with Azophosmet and humic acid $\left(\mathrm{S}_{2}\right)$ showed the maximum pod yield of $23.79 \mathrm{t} / \mathrm{ha}$, whereas minimum in 75 per cent recommended dose of fertilizers as straight fertilizer with Azophosmet and humic acid, $\left(\mathrm{S}_{7}\right)$ the pod yield per hectare was $11.56 \mathrm{t} / \mathrm{ha}$.

The increase in yield might be due to better proportion of air-soil-water which was maintained throughout the life period of crop in drip fertigation as reported by Kadam and Karthikeyan [18]. The result of this experiment indicated that total yield was affected by plant density. Yield per hectare increased as plant density decreases. Nasto et al. [19] reported that the greatest fruit yield of sweet pepper and other plants were obtained from plants grown at low density. Lower planting densities per unit area produces more vigorous crops than higher population density, but this could not compensate for a reduced number of plants per unit area. The total yield increased with lower planting densities. This was probably due to decrease in the number of plants per unit area, which might contribute to the production of extra yield per unit area leading to high yield [20].

\subsection{Economic Viability}

In the present study, application of 100 per cent recommended dose of fertilizer as water soluble fertilizer along with Azophosmet and humic acid under drip fertigation at wider spacing secured the highest net return (Rs. $162840.40 / \mathrm{ha}$ ). This resulted in the production of higher yield per hectare with higher cost benefit ratio (Table 2). The treatment drip fertigation at 100 per cent recommended dose of fertilizer as water soluble fertilizer along with Azophosmet and humic acid under wider spacing recorded the maximum BCR of 2.99. The lower BCR of 1.40 were recorded in the treatment 75 per cent recom-

Table 2. Effect of spacing and drip fertigation on economic viability of hybrid bhendi.

\begin{tabular}{|c|c|c|c|c|c|c|c|c|c|c|}
\hline \multirow{3}{*}{ Treatments } & \multicolumn{10}{|c|}{ Economic Viability } \\
\hline & \multicolumn{2}{|c|}{$\begin{array}{c}\text { Economic yield } \\
\text { (Kg/ha) }\end{array}$} & \multicolumn{2}{|c|}{$\begin{array}{l}\text { Gross income } \\
\text { (Rs/ha) }\end{array}$} & \multicolumn{2}{|c|}{$\begin{array}{l}\text { Cost of cultivation } \\
\text { (Rs/ha) }\end{array}$} & \multicolumn{2}{|c|}{$\begin{array}{l}\text { Net return } \\
\text { (Rs/ha) }\end{array}$} & \multicolumn{2}{|c|}{ BCR } \\
\hline & $\begin{array}{c}\text { Wider } \\
\text { spacing }\end{array}$ & $\begin{array}{c}\text { Closer } \\
\text { spacing }\end{array}$ & $\begin{array}{c}\text { Wider } \\
\text { spacing }\end{array}$ & $\begin{array}{c}\text { Closer } \\
\text { spacing }\end{array}$ & $\begin{array}{c}\text { Wider } \\
\text { spacing }\end{array}$ & $\begin{array}{c}\text { Closer } \\
\text { spacing }\end{array}$ & $\begin{array}{l}\text { Wider } \\
\text { spacing }\end{array}$ & $\begin{array}{c}\text { Closer } \\
\text { spacing }\end{array}$ & $\begin{array}{c}\text { Wider } \\
\text { spacing }\end{array}$ & $\begin{array}{l}\text { Closer } \\
\text { spacing }\end{array}$ \\
\hline $\mathrm{S}_{1}$ & 22.10 & 21.25 & 220998.20 & 212554.65 & 89005.53 & 89005.53 & 131992.67 & 123549.12 & 2.48 & 2.39 \\
\hline $\mathbf{S}_{2}$ & 24.47 & 23.12 & 244676.24 & 231223.69 & 81835.84 & 81835.84 & 162840.40 & 149387.85 & 2.99 & 2.83 \\
\hline $\mathbf{S}_{3}$ & 17.95 & 17.44 & 179498.43 & 174420.09 & 74894.79 & 74894.79 & 104603.64 & 99525.30 & 2.40 & 2.33 \\
\hline $\mathrm{S}_{4}$ & 19.79 & 18.78 & 197854.25 & 187744.81 & 80860.84 & 80860.84 & 116993.41 & 106883.97 & 2.45 & 2.32 \\
\hline $\mathbf{S}_{5}$ & 21.18 & 20.37 & 148298.75 & 142590.84 & 64515.94 & 64515.94 & 83782.81 & 78074.91 & 2.30 & 2.21 \\
\hline $\mathbf{S}_{6}$ & 16.30 & 15.81 & 122211.94 & 118556.34 & 63076.95 & 63076.95 & 59134.99 & 55479.39 & 1.94 & 1.88 \\
\hline $\mathbf{S}_{7}$ & 11.81 & 11.30 & 88552.24 & 84783.69 & 60662.96 & 60662.96 & 27889.27 & 24120.73 & 1.46 & 1.40 \\
\hline $\mathrm{S}_{8}$ & 13.77 & 13.25 & 103287.60 & 99403.42 & 62101.95 & 62101.95 & 41185.65 & 37301.47 & 1.67 & 1.60 \\
\hline
\end{tabular}


mended dose of fertilizers as straight fertilizer along with Azophosmet and humic acid under closer spacing in the experiment.

\section{Conclusion}

Thus from the present investigation, drip fertigation under wider spacing in bhendi was found to be an economically viable, technically feasible, socially acceptable technology for maximum yield and income benefits. It can be concluded from the foregoing discussion that drip fertigation at 100 per cent recommended dose of fertilizer as water soluble fertilizer along with Azophosmet and humic acid was utilizing the input efficiently in all the seasons under wider spacing $(60 \times 45 \mathrm{~cm})$.

\section{REFERENCES}

[1] R. Dhanraj, Om. Prakash and I. P. S. Ahlawat, "Response of French Bean (Phesolus vulgaris) Varieties to Plant Density and Nitrogen Application," Indian Journal of Agronomy, No. 46, 2001, pp. 277-281.

[2] K. Anilkumar, "Standardization of Seed Production Techniques in Fenugreek," M.Sc. Thesis, University of Agricultural Sciences, Dharwad, 2004.

[3] S. N. Mazumdar, M. Moninuzzaman, S. M. M. Rahman and N. C. Basak, "Influence of Support Systems and Spacing on Hyacinth Bean Production in the Eastern Hilly Area of Bangladesh,” Legume Research, Vol. 1, No. 30, 2007, pp. 1-9.

[4] A. Mantell, H. Frenkel and A. Meiri, "Drip Irrigation of Cotton with Saline Sodic Water," Irrigation Science, Vol. 6, No. 2, 1985, pp. 95-106. doi:10.1007/BF00251558

[5] R. S. Malik, K. Kumar and A. R. Bhandari, "Effect of Urea Application through Drip Irrigation System on Nitrate Distribution in Loamy Sand Soils and Pea Yield," Journal of the Indian Society of Soil Science, Vol. 1, No. 42, 1994, pp. 6-10.

[6] B. Bar Yosef and B. Sagiv, "Response of Tomatoes to N and Water Applied via Trickle Irrigation System, I. Nitrogen,” Agronomy Journal, No.74, 1982, pp. 633-637.

[7] S. P. Palaniappan, "Cropping Systems in the TropicsPrinciples and Management," Wiley Eastern Ltd., New Delhi, 1985, p. 215.

[8] H. C. Takahashi, Shennan and R. C. Huffaker, "Agronomical and Physiological Studies on Zinc Deficiency in Crop Plants, Effect of Zinc Concentration in Nutrient Solution and Shading on Growth, N Content and Nitrate Reductase Activity in Tomato," Nettai Nogyo, Vol. 1, No. 37, 1993, pp. 22-27.

[9] I. Cakmak, "The Role of Potassium in Alleviating Detri- mental Effects of Abiotic Stresses in Plants,” Proceedings of the IPI Congress on Feed the Soil to Feed the People: The Role of Potash in Sustainable Agriculture, Basel, October 2002, pp. 8-10.

[10] K. Ramalingam, "Effect of Growth Regulating Substances on Growth, Yield and Post Harvest Quality of Cut Rose cv. Happy Hour,” M.Sc. Thesis, Tamil Nadu Agricultural University, Coimbatore, 2008.

[11] R. Balakumbahan, "Studies on Standardization of Pre and Post Harvest Treatments in Gloriosa superba L,” Ph.D. (Hort.) Thesis, Tamil Nadu Agricultural University, Coimbatore, 2008.

[12] J. L. Salvadore, G. J. Hochmuth, M. R. Fred, S. M. Olson, A. G. Smajstrala and A. Honlon, "Nitrogen and Potassium Application Scheduling Effects on Drip Irrigated tomato Yield and Leaf Tissue Analysis," Horticultural Science, Vol. 32, No. 2, 1997, pp. 230-235.

[13] M. Prabhakar, C. Vijaya Savanur, L. Naik and V. Savanur, "Fertigation Studies in Hybrid Tomato," South Indian Horticulture, No. 49, 2001, pp. 98-100.

[14] N. Meenakshi and E. Vadivel, "Effect of Fertigation on Growth and Dry Matter Production of Hybrid Bitter Gourd (Momordica charantia L.)," Orissa Journal of Horticulture, Vol. 2, No. 31, 2003, pp. 33-34.

[15] M. Kavitha, "Studies on Effect of Shade and Fertigation on Growth and Yield of Tomato (Lycopersicon esculenttum Mill.) Hybrid Ruchi,” Ph.D. Thesis, Tamil Nadu Agricultural University, Coimbatore, 2005.

[16] A. Muscolo, M. Felici, G. Concheri and S. Nardi, "Effect of Earthworms, Humic Substances on Esterase and Peroxidase Activity during Growth of Leaf Explants of Nicotiana plumbaginifolia," Biology and Fertility of Soils, No.15, 1993, Pp. 127-131.

[17] R. Balumahendran, "Effect of Biostimulants on Yield and Postharvest Quality of Gladiolus cv. White Prosperity," M.Sc. Thesis, Tamil Nadu Agricultural University, Coimbatore, 2008.

[18] J. R. Kadam and S. Karthikeyan, "Effect of Soluble NPK Fertilizers on the Nutrient Balance, Water Use Efficiency, Fertilizer Use Efficiency of Drip System in a Tomato," International Journal of Plant Sciences, No. 1, 2006, pp. 92-94.

[19] T. H. Nasto, A. Balliu and N. Zeka, "The Influence of Planting Density on Growth Characteristics and Fruit Yield of Peppers (Capsicum annuum L.)," Acta Horticulturae, No. 830, 2009, pp. 906-912.

[20] O. K. Law and E. Egharevba, "Effects of Planting Density and NPK Fertilizer Application on Yield and Yield Components of Tomato (Lycopersicum esculentum Mill) in Forest Location," World Journal of Agricultural Sciences, Vol. 5, No. 2, 2009, pp. 152-158. 


\section{List of Abbreviations}

RDF: Recommended dose of fertilizer

DAS: Days after sowing

BCR: Benefit cost ratio

NPK: Nitrogen, Phosphorus and Potassium

SF: Straight fertilizer

WSF: Water soluble fertilizer
SSP: Single super phosphate

MAP: Mono ammonium phosphate

SPD: Split plot design

MOP: Muriate of potash

Rs./ha: Rupees/Hectare

Kg/ha: Kilogram/Hectare 